\title{
Reflection in the Elementary Music Ear Training
}

\author{
Milena Bogdanova \\ Department of Theory and History of Music, Faculty of Music Pedagogy, Academy of Music, Dance and Fine Arts, Plovdiv, Bulgaria
}

Email address:

milena_bogdanova@abv.bg

To cite this article:

Milena Bogdanova. Reflection in the Elementary Music Ear Training. International Journal of Literature and Arts. Special Issue: Musical Theory, Psychology, Pedagogy and Performing. Vol. 3, No. 5-1, 2015, pp. 14-24. doi: 10.11648/j.ijla.s.2015030501.12

\begin{abstract}
This article discusses an issue, concerning musical theory and in particular music pedagogy. As working, the terms reflection and reflection activity were used and their positive practical application was indicated. This, of course, leads to didactics. It was proposed as an attempt for psychological practical and applied analysis of a specific education practice solfegging with piano self-accompaniment. The author of this article is motivated by the concept of pointing new aspects to the work forms and methods for the music ear education in the solfege training.
\end{abstract}

Keywords: Solfege, Solfegging, Ear Training, Musical Ear, Reflection

\section{Introduction}

The problems of education are priority with permanent "presence" in the public life. As content, they are related to the quality of education, the development of learning abilities, accompanied by rationalization of experience. Music education is a process that should satisfy the needs of the practice. This requires binding of its effectiveness with the qualities necessary for the professional realization of every musician. According to this, the search, research and application of modern educational technologies and effective pedagogical practices are significant. On the one hand, this is a way to arouse interest among young people for musical art activities; on the other hand - a successful strategy that can meet the steadily increasing educational needs.

Today, the resources available to education do not increase at the same pace as educational needs increase. Therefore it is necessary to put impetuous on the tasks of all pedagogues constantly to seek and implement alternative approaches activities to provoke the formation of self-knowledge abilities and self-critical attitudes, thanks to which the learner is able to be self-controlled, self-managed and continuously able to develop and self-improve. The presence of such abilities ensures the successful conduct of the educational and learning process and stimulates self-education. The forementioned abilities are complex interpersonal new forms that have an applied and practical value. For such, I would say fundamental personality abilities; the educational psychology uses the term reflection.

\section{Subject, Purpose and Tasks of the Research}

Subject of the research is the activity of solfegging with piano self-accompaniment. This article presents specific didactics related to the preparatory stage of the actual implementation of the activity. Specific exercises and ways of working, suitable for the elementary music ear education were proposed.

The purposes of the research are as follows:

- to examine the role of the activity of solfegging with piano self-accompaniment in the practical learning of the various means of musical expression;

- to monitor its complex theoretical, practical and educational significance for the development of the musical ear;

- to analyze the influence of the activity on the aural and intonation education of the students and the enrichment of their musical experience;

- to justify the place of the solfegging with piano selfaccompaniment along with the main activities in the ear training lessons;

- to propose a system of exercises.

- A number of particular tasks derived from the specified goals:

- to present and analyze the specific characteristics of the activity of solfegging with piano self-accompaniment and their relationship with the accompanying forms of psychical activity; 
- to present and analyze the existing didactic literature, which includes in its content solfegging with individual piano accompaniment;

- to create and systematize constructive examples for solfegging with piano self-accompaniment, each of which to be directed to the learning of a particular music element - intervals, tone system, tonalities, metrorhythmic groups, functional harmonic relationships and dependencies etc.

- to prove the hypothesis experimentally by implementing the proposed method in the practice of the learning process.

\section{Basic Concepts}

\subsection{Reflection}

Reflection (comes from Latin) means meditation, introspection, self-study, analyzing your own thoughts and experience. In psychology, reflection is considered in an individually psychological aspect - self-reflection. It is characterized as a cognitive process, a system of individual's research actions that brings new knowledge.

The following part presents a reflexive activity, applicable to elementary music ear education. The content is a direct result of personal professional experience. The further mentioned didactic principles and specific examples are concepts of the author based on an extensive theoretical research, which allowed the creation of an integral system, optimizing successfully the ear training. The system complies with the established laws of learning, formation and psychological development of personality. A basic principle is the observance of the transition dialectics from education to self-education. The discussed learning activity has a clear psychological characteristic which corresponds to the modern educational trends and gives reason to be referred to as reflexive.

The activities associated with music ear education have a long history. Through them training for introduction and "speaking" of the music language is carried out. Looking back at the history of music ear education and comparing different music pedagogical practices it becomes apparent that the activity of solfegging is initial in time and nature. It gives the title and is the prototype of the studied discipline solfege. The fore-mentioned argues the general conclusion ear training means solfege and solfege is initially understood as solfegging - singing with sol-fa syllables.

\subsection{Solfegging with Accompaniment}

In this article singing with sol-fa syllables is presented as a learning activity by a subspecies - solfegging with piano accompaniment. The following part includes new systematized tools and ways of working that allow better approbation of the educational technologies system aimed at developing music ear.

The learning activity solfegging with piano accompaniment is a term consisting of: solfegging and accompaniment. The first one (solfegging) is understood as an activity that provides reading technique of musical score by voice as well as a method of rationalizing the artistic content and expressiveness of the musical score. Piano accompaniment should be understood regarding the second term. An argument supporting this is not the fact that the piano instrument is traditionally used in the ear training. The main reason is the symbiosis between the visual, aural and motor demonstrativeness created by the piano keyboard. Because the activity is provided as solfegging with piano self-accompaniment, it becomes clear that a preliminary "acquaintance" with this musical instrument is needed in advance. The level of playing the instrument is low in the beginning and is limited to naming the keys, location of tones, making connections between tone - name - note - key. During the training process we observe the gradual complication of the piano texture, which also brings positive results in the development of the instrumental skills of the learners - this applies especially to children who study a different instrument than the piano. The combination of the two terms in one general - solfegging with accompaniment, creates an overall learning activity with the below explanations concerning didactics in its implementation.

\section{The Condition of the Solfege in Bulgaria}

From an early age learners begin forming habits of singing with sol-fa syllables based on the known methodology forms (imitative singing with sol-fa syllables - subordinate solfegging, learning the note signs, corresponding to the tone names and the note values in natural $\mathrm{C}$ dur). Further in the training, the hearing is educated only by using the voice and various visual aids. In most solfege books that illustrate the methodology for the musical ear development, examples of solfegging with accompaniment are quite scarce. Despite being sporadic, the examples including the solfegging with accompaniment displays the authors understanding of the importance of this activity in the training, but specific methodological guidelines for its implementation, as well as systematization of the material at any criteria are missing.

It is important to stress that in the mentioned books the term accompaniment is interpreted in general, broad sense, such as piano or another musical instrument accompaniment performed by the teacher or as accompaniment by one or more voice parts, etc. The presented article examines the learning activity solfegging with accompaniment specifically implemented as solfegging with piano self-accompaniment.

\section{Method for Music Ear Education through the Activity Solfegging with Piano Self-Accompaniment}

The adoption of the necessary skills and habits for solfegging with piano self-accompaniment is a complex 
process that requires the need of a multifunctional method. For this purpose, preparatory exercises are introduced in early childhood and in the solfege lessons of children from the so-called zero preparatory classes. The proposed approach is well co-ordinated with the provided activities for these classes and its usefulness complements the planned curriculum tasks.

In the beginning preparatory exercises in solfegging with timber and rhythmic accompaniment are conducted, for the purpose of developing free, equal and symmetric skills in both hands.

The next step in the method is associated with the introduction of the pitch parameters of musical language. The suggested exercises therein are separate in groups according to the manner of performance:

- Examples - "dialogue" between piano and voice.

Examples - "coordination" between piano and voice:

- with duplication of the melody in the accompaniment; without duplication of the melody in the accompaniment.

The provided exercises have a common goal, but emphasize on specific angles on the way to the actual implementation of the activity solfegging with piano self- accompaniment on original music compositions.

For mastering the pitch parameters of the musical language through solfegging with piano self-accompaniment two activities are used:

a). learning the position of the tones on the piano keyboard with their syllable names;

b). acquisition of practical and applied knowledge vocal, instrumental skills and elementary theoretical knowledge.

That "ideological platform" is presented in the following sequence and content:

a). acquaintance with the keyboard is provided through:

- presentation of the piano keyboard (a set of recurrent black and white keys), which illustrates the tones of the music system;

- presentation of the shortest distance between the notes in the equal temperament (semitone) and the sum of two semitones - a whole tone;

- formation of aural concepts for semitone and whole tone by playing and singing the following exercise simultaneously:

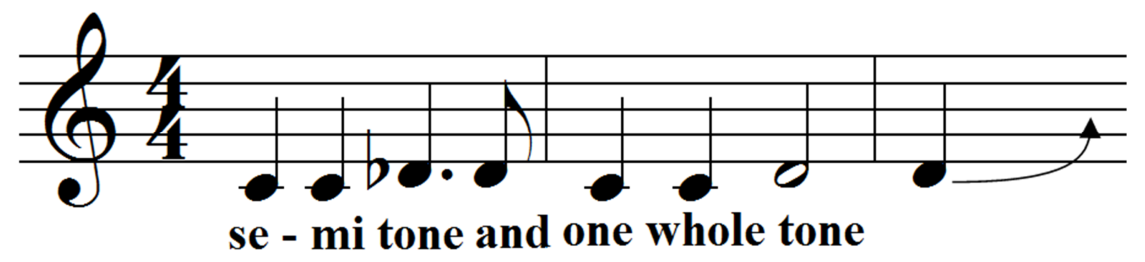

Figure 1. Semitone and one whole tone.

- naming, pointing, playing and singing single notes with the syllables on their corresponding key.

b). Introducing the performance of:

- sequences (developed in a specific order);

- constructive examples.

The proposed exercises "contain" fundamental problems of the elementary music ear education. They clarify the direction of melodic movement, gradual or intermittent melodic movement, uniformity, similarity or difference between melodic lines, volume of different melodic and harmonic intervals, various tonal durations etc. Simultaneously, each example contributes to the gradual formation of skills for playing the piano. Thus, by practicing the activity, "the combined" concepts have a simultaneous effect, fixing pitch parameters, connecting them with various modal and rhythmic manifestations in music. Each exercise enriches, clarifies and consolidates the aural concepts, provides the acquisition of skills and habits for pure intonation, playing the piano, development of sight reading technique, initial theoretical knowledge of music elements, etc.

The exercises in the group "dialogue" between piano and voice aim to:

- create a visual concept for the tone position on its corresponding key;
- create a motive concept for the playing of the tone;

- getting aural perception of the tone;

- create skills for pure intonation of the tone.

In these exercises solfegging (individual's voice timbre) "contrast" to the piano timbre, that stimulates the "understanding" of timbre. And last but not least, each examples of the given intonation exercises (sequences) below is "named after": quantitative value of an interval, name of the tone system, position of a triad etc. By brief explanations, illustrated during the performance, the learner receives initial musical theory knowledge.

The examples below are presented in order of study, according to the set methodic goals:

- gradual building of aural concepts, serving to support future music perceptions;

- formation of images by which the attention, memory and thinking operate later.

"The implied meaning" of the proposed order is to expand the working memory. Stored information from previous exercises is used in each following example. Remodeling is carried out, i.e. the information is amended and enriched.

The exercises are performed as follows:

- the proposed pattern is shifted a second upwards and downwards until reaching its octave equivalent;

- the learner solfegges the pattern and then plays it on 
the piano;

- while solfeging, the student touches the corresponding keys of the tones, and says the tone names while playing.

In teaching absolute beginners the order of the activities solfegging $\rightarrow$ playing (in the examples) should be changed playing $\rightarrow$ solfegging. This happens at the discretion of the teacher.

\subsection{Sequences}

Playing the patterns in all exercises (except for Figure 2) is done legato as follows:

- in shifting the pattern upward right hand plays, and shifting it downward - the left one;

- in shifting the pattern the indicated fingering is kept.

The reason for the requirement to have the same fingering for identical patterns is that the traces remaining in the cortex, derived from muscle and joint perceptions are used to form additional conditioned reflex connections (visual motor and auditory motor conditioned reflexes) to produce the physiological basis of the music aural concept.

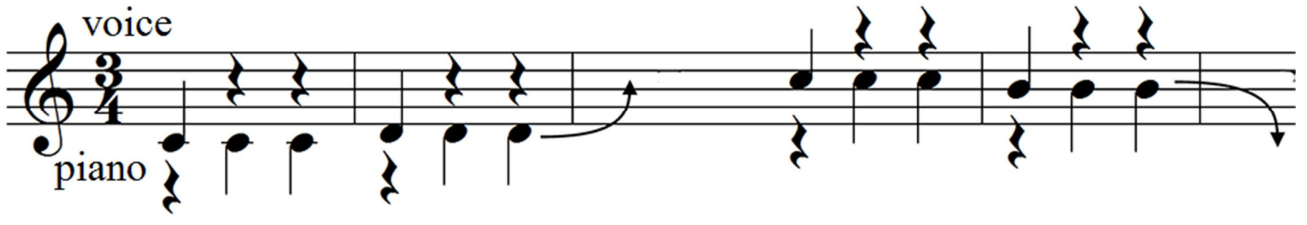

Figure 2. Monochord"(,Prima“).

Figure 2. "Monochord“(„Prima“).

The learner solfegges a tone (with its corresponding syllable name) and immediately after he/she "confirms" it as sound and position of the piano keyboard. The piano accompaniment is performed by alternating left and right hands in non-legato, with second or third fingers. The exercise can be performed by three, four children simultaneously - each child playing in a different octave set. Thus, aural concepts for different sounds registers are created. The term "octave set" is explained by visual aids and the children learn the names of the different octave sets of the musical system.

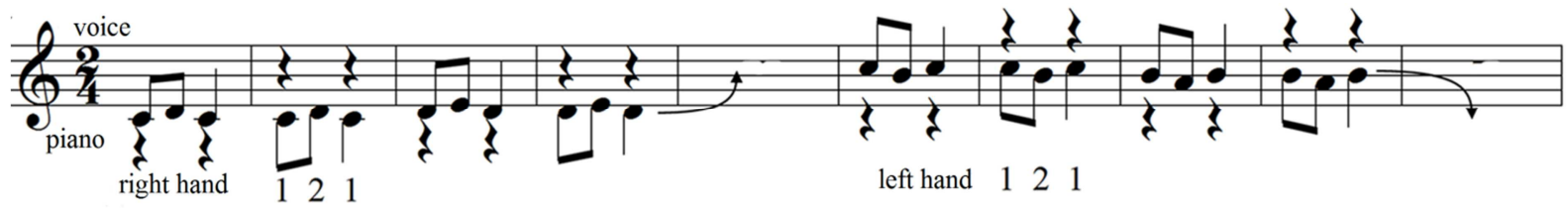

Figure 3a). Dichord.

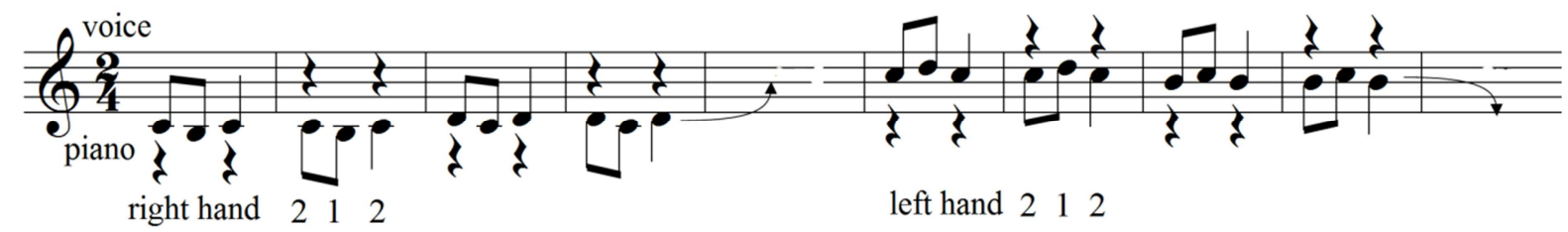

Figure 3b). Dichord.

"Dichord" - the knowledge of the syllable names of the tones is assimilated as well as their sounding and position on the piano keyboard. Moreover, it forms aural concepts for upwards and downwards neighboring motion.
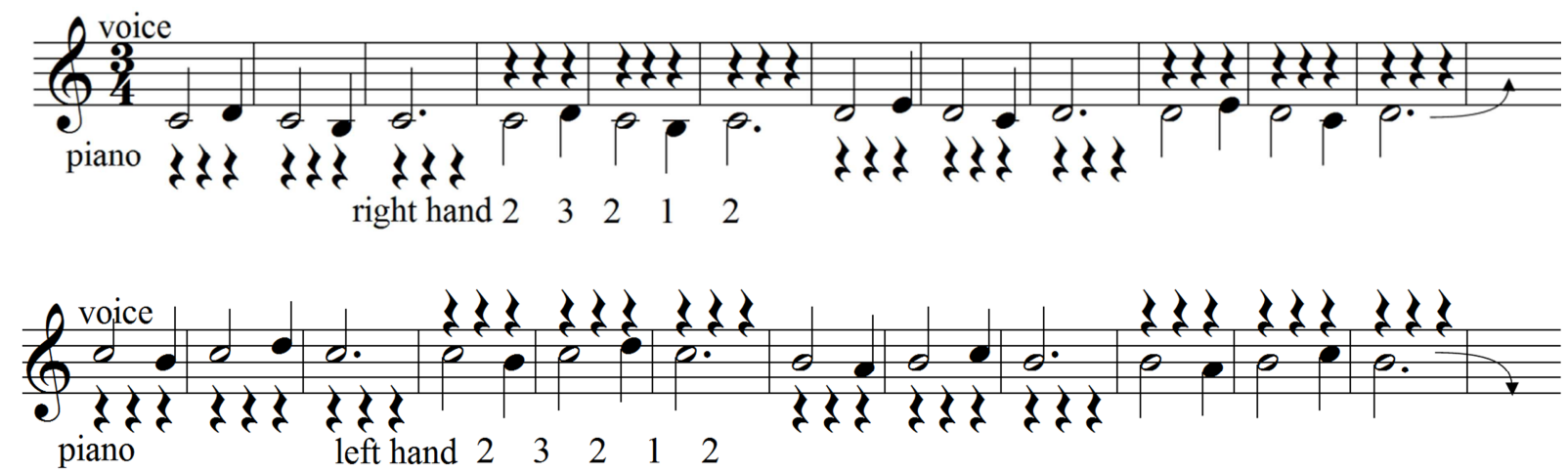

Figure 4a). Second. 


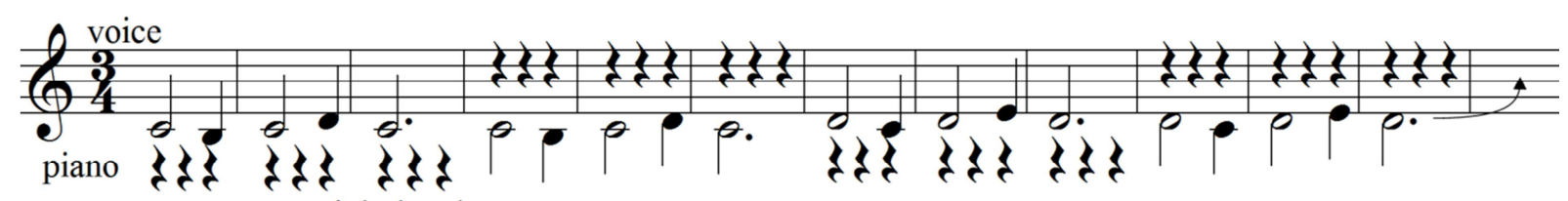

right hand $\begin{array}{lllll}2 & 1 & 2 & 3 & 2\end{array}$

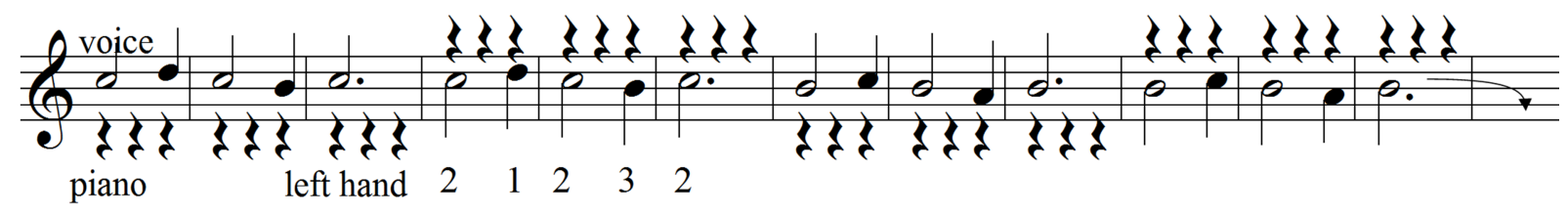

Figure 4b). Second.

"Second" - the aural concepts for upwards and downwards neighboring motions of the melody (prepared by the performance of Figure $3 \mathrm{a}$ and $3 \mathrm{~b}$ ) are consolidated. The phrase is extended to trichord tone system. The learner's attention is directed to the building, intonation and playing seconds upwards and downwards consecutively by one tone. The example is given in 3/4 time signature. The half notes, through their long duration, are intended to emphasize the initial tones of the ascending and descending motion of the second.

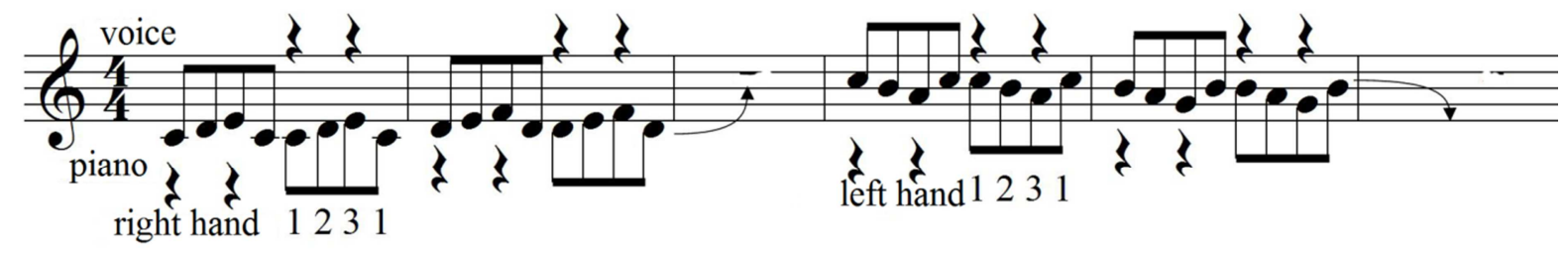

Figure 5a). Trichord.

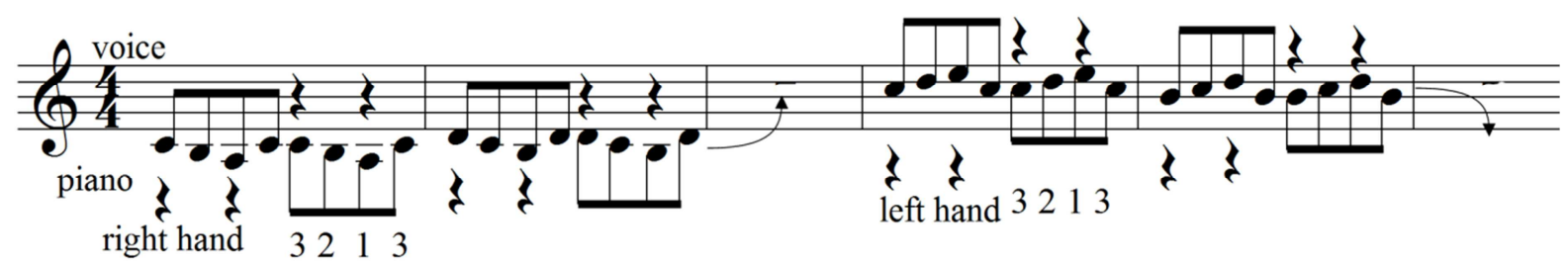

Figure 5b). Trichord.

"Trichord" - The proposed leap at the end of the phrases is easily perceived and assimilated as the tone to which the leap is provided is initial for each phrase. Thus the leap appears prepared - the initial tone is "sealed" in the memory.

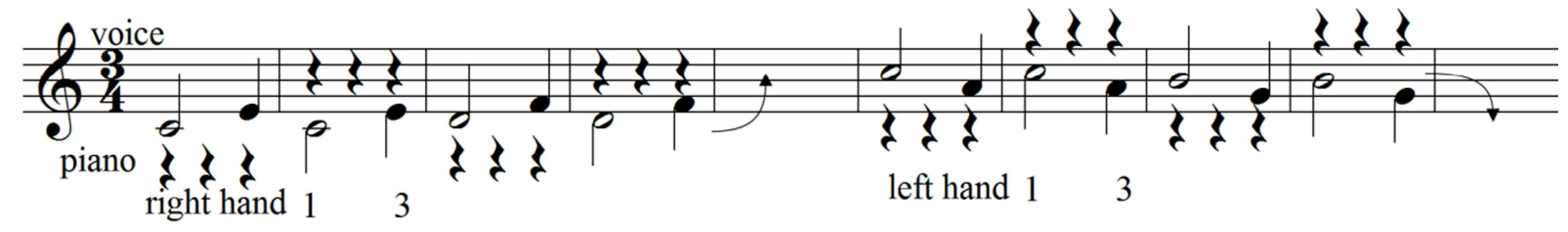

Figure 6a). Third.

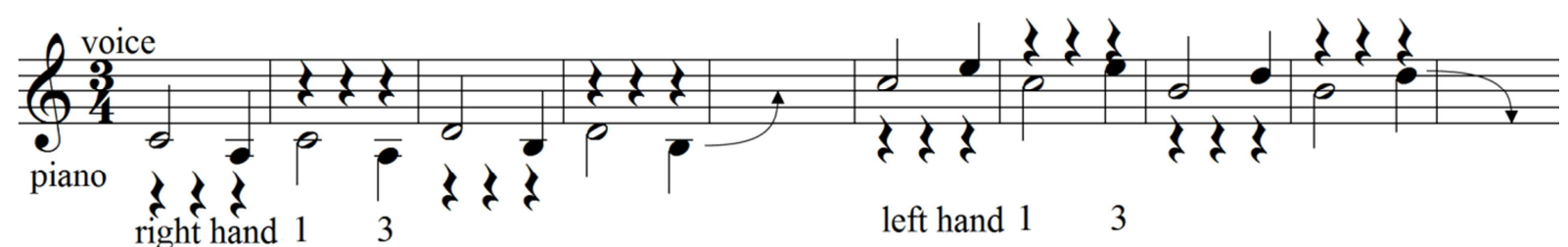

Figure 6b). Third.

„Third“ - This example is aimed at consolidating the aural concept for melodic third leap. The pattern, which is shifted neighboringly is given in $3 / 4$ time signature. The main tone of the third is a half note, in order to give the learner time to 
imagine a trichordal tone system (prepared as the aural concept of Figure 4) before implementing the intonation of the side tone. Similarly, with the same purpose are presented the following examples in 3/4 time signature. The pattern that consists of a descending third leap (Figure 6b) is shifted upwards. An ascending fourth leap is carried out between the units of the sequences.

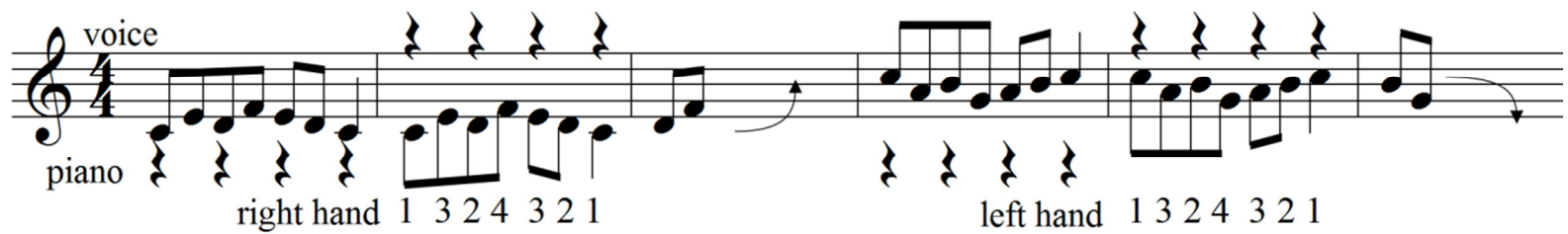

Figure 7a). Tetrachord.

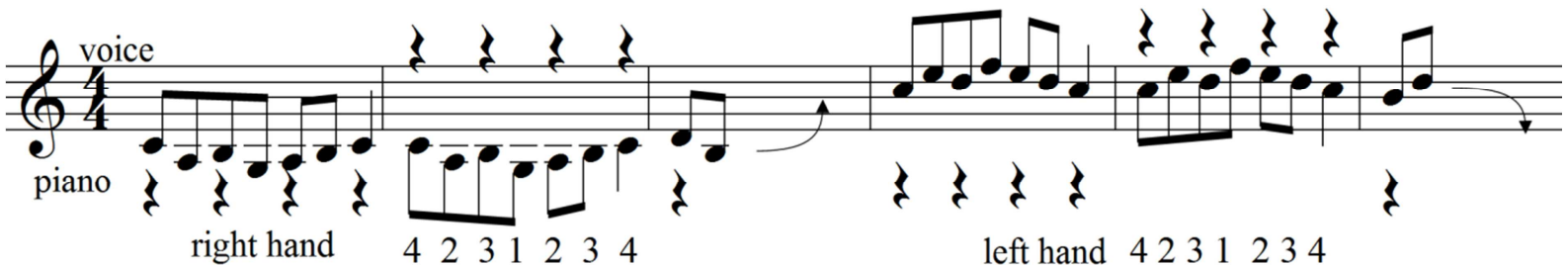

Figure $7 b)$. Tetrachord

"Tetrachord" - In these examples, the phrase is expanding, joining the prepared from the performance of the previous examples melodic moves of the second and the third, presenting to the learner ascending and descending tetrachord tone systems.
In the upward shifting of the main motif (Fig. 7b, built by two "overlapping" descending third leaps, followed by an ascending tetrachord), an upward pentachord tone system is carried out, respectively, in the downward shifting downward pentachord tone system.

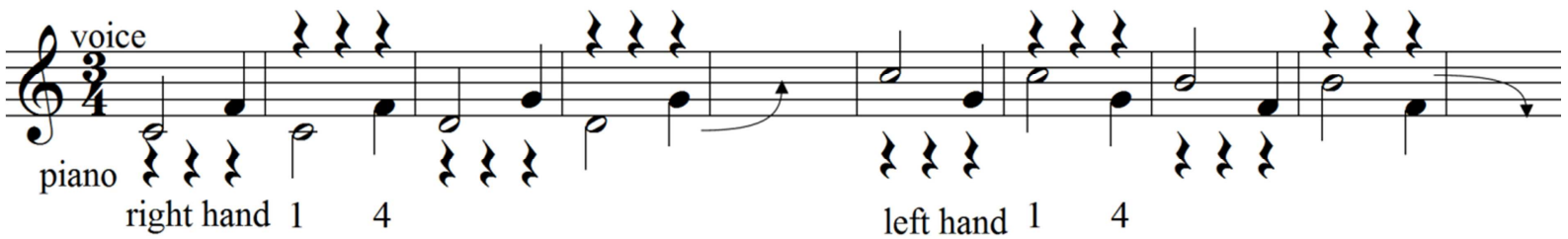

Figure 8a). Fourth.

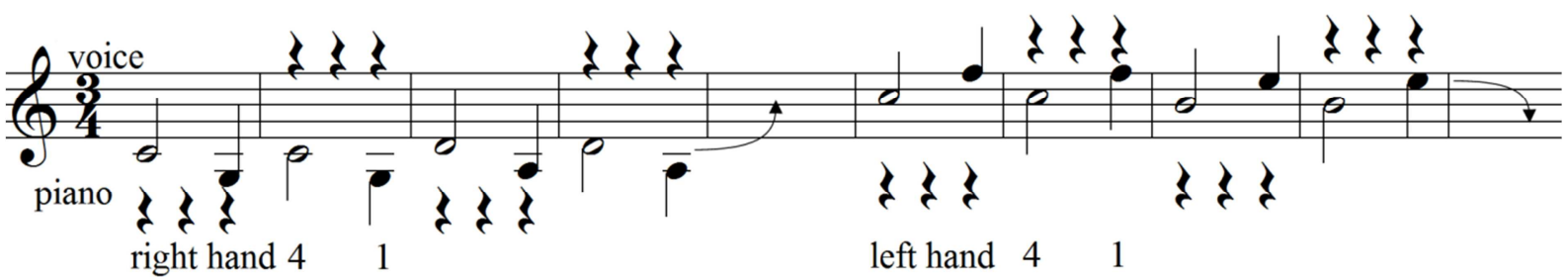

Figure 8b). Fourth.

„Fourth"- These examples are aimed at consolidating the aural concept for melodic fourth leap. The learner has aural perceptions of the interval fourth (Figure $6 \mathrm{~b}$ ) and tetrachord tone system (Figure 7). The main motif built by a descending fourth leap is shifted upward (Figure 8b), thus an upward fifth leap is carried out between the units of the sequence, respectively, in the downwards shifting - descending fifth leap.

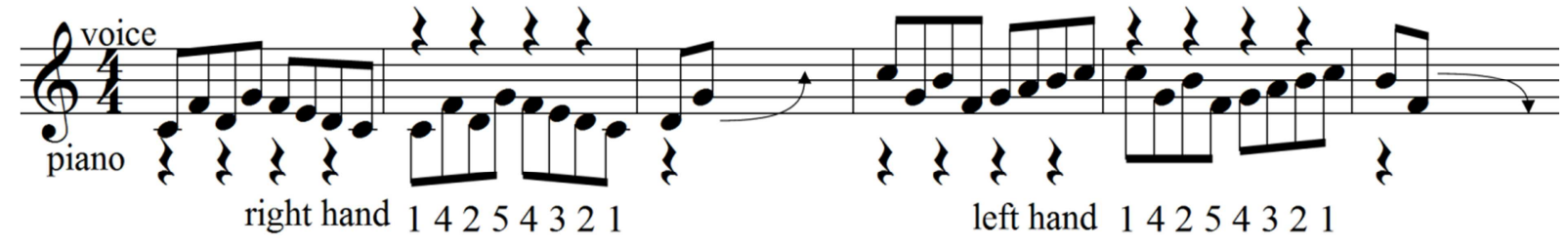

Figure 9a). Pentachord. 


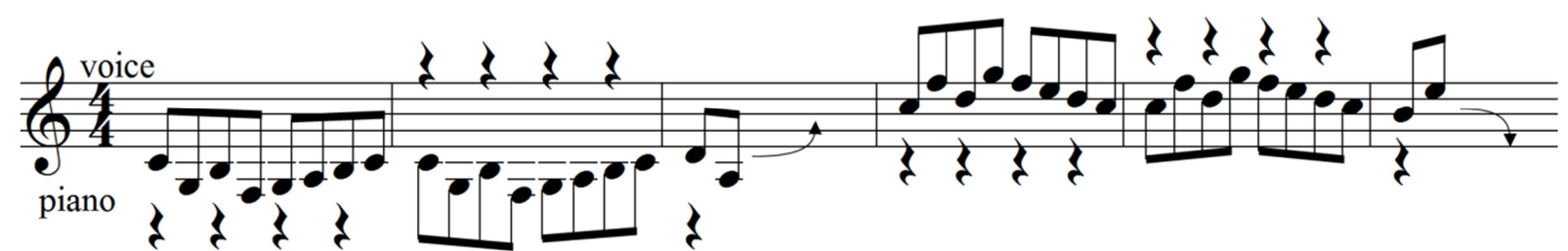

right hand 52412345

left hand 52412345

Figure 9b). Pentachord.

"Pentachord"- In these examples, we use the already created musical aural concepts of melodic fourth leaps (Figure 8a and $8 \mathrm{~b}$ ). The phrase is expanding, presenting the learner upwards and downwards pentachord tone systems. The main motif, built by two "overlapping" descending fourth leaps followed by a descending pentachord (Fig. 8b) is shifted upwards. Thus, an upward hexachord tone system is carried out between the phrases. After reaching the octave equivalent of the main motif, its mirror image is shifted downwards. There is a downwards hexachord tone system between the phrases.

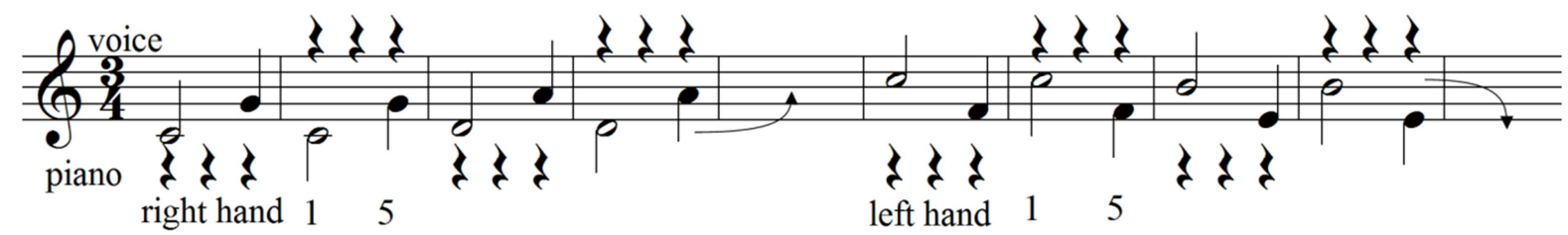

Figure 10a). Fifth.

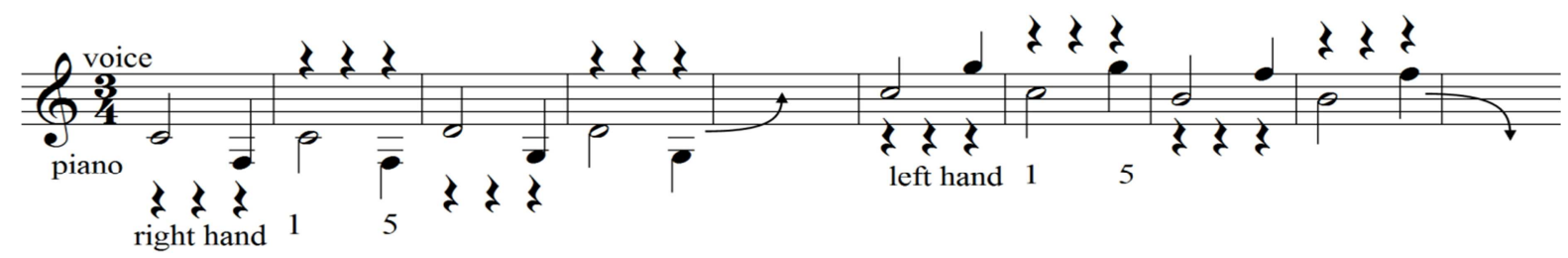

Figure 10b). Fifth.

"Fifth" - The main motif, built by a descending fifth leap is shifted upwards, so thereby an upwards sixth leap is carried out between the sequence segments, respectively, in the descending shifting - descending sixth leap. Figure 10b) is aimed at consolidating the aural concept of melodic fifth leap. The learner already has an aural concept for the fifth (Figure 8b) and pentachord tone system (Figure 9).

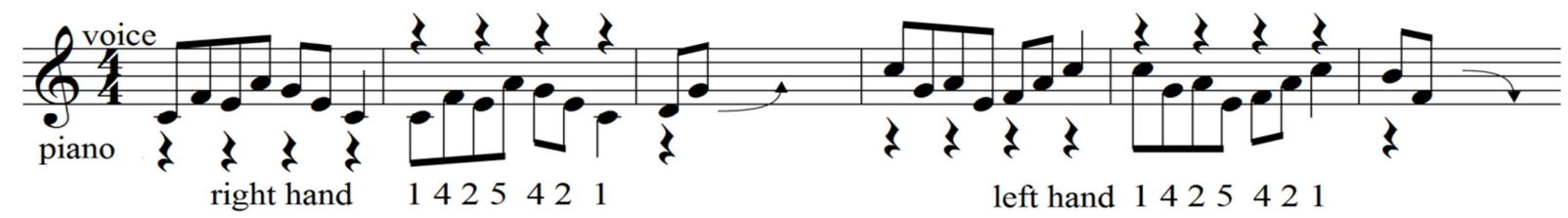

Figure 11. Root Position Triad.

Figure 11: - ,Root Position Triad“ - Through the prepared by the performance of the previous examples third and fourth melodic moves, in this example the learner gets to know to the term triad in its root position.

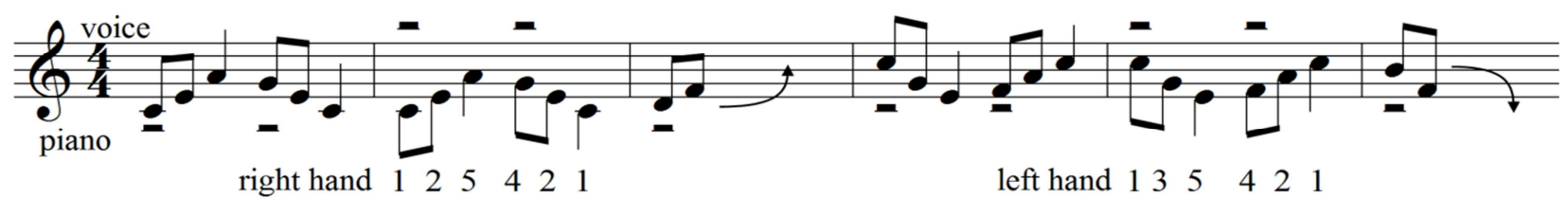

Figure 12. First Inversion Chord.

Figure 12: - ,First Inversion Chord“ - In this example the learner consolidates his knowledge of the root position and gets to know to its first inversion - a triad with the third of the chord in the bass. 


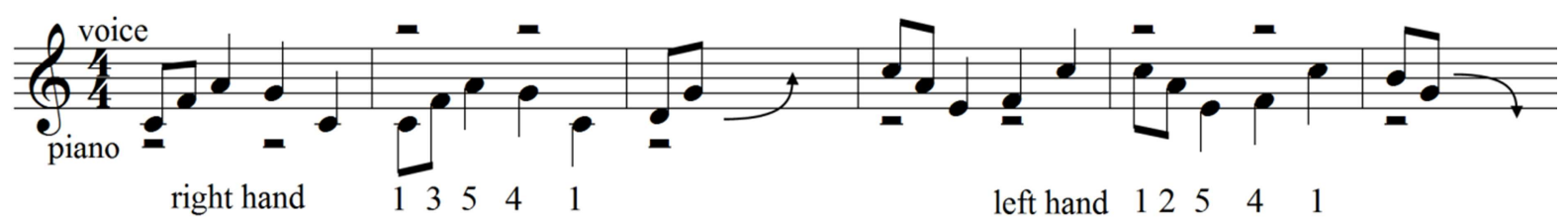

Figure 13. Second Inversion Chord.

Figure 13: - „Second Inversion Chord“- In this example the fifth of the chord in the bass. the learner gets to know to the second inversion - a triad with

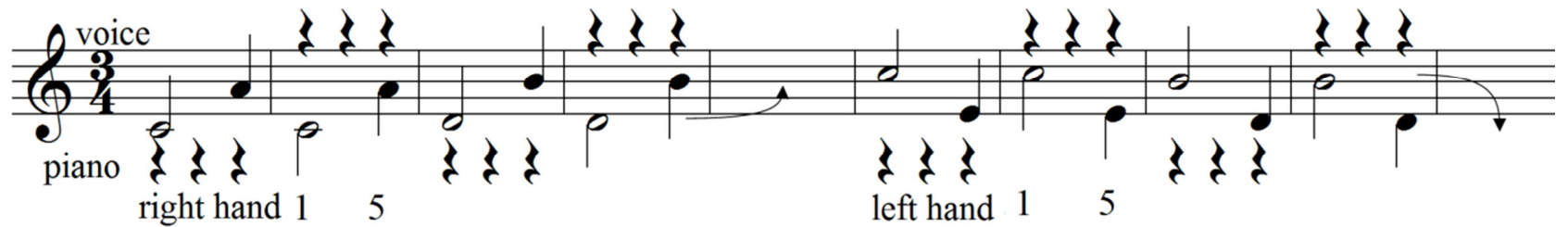

Figure 14a). Sixth.

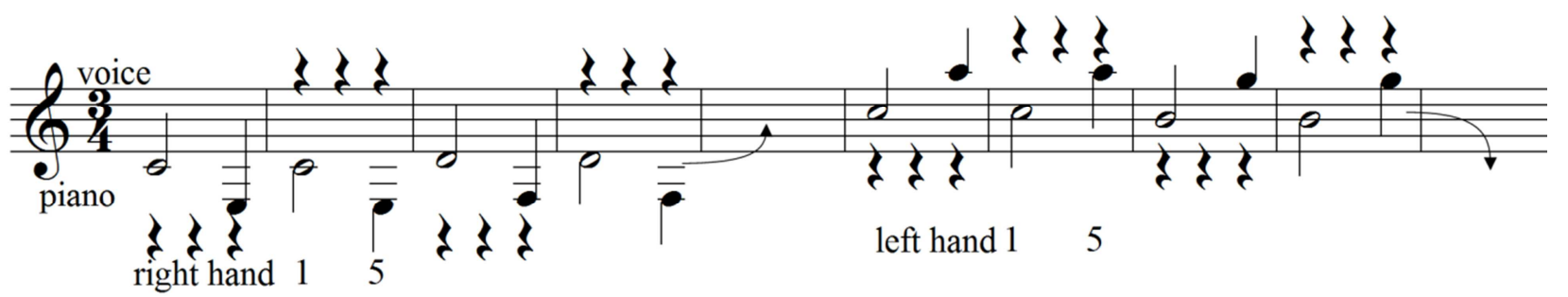

Figure 14b). Sixth.

"Sixth"- This example is intended to reinforce the aural concept for melodic sixth leap. The learner already has aural perceptions of the sixth by the performance of Figure 10b). The pattern which is shifted neighbourly is given in 3/4 time signature. The main tone of the sixth is a half note, in order to give the learner time to imagine a triad - first inversion or second inversion chord (prepared as a aural concept by Figure 12 and 13) before implementing the intonation of the side tone. The main motif, built by a descending sixth leap (Fig. 14b) is shifted upwards. An upward seventh leap is carried out between the sequence segments, respectively, in the descending shifting - descending seventh leap.

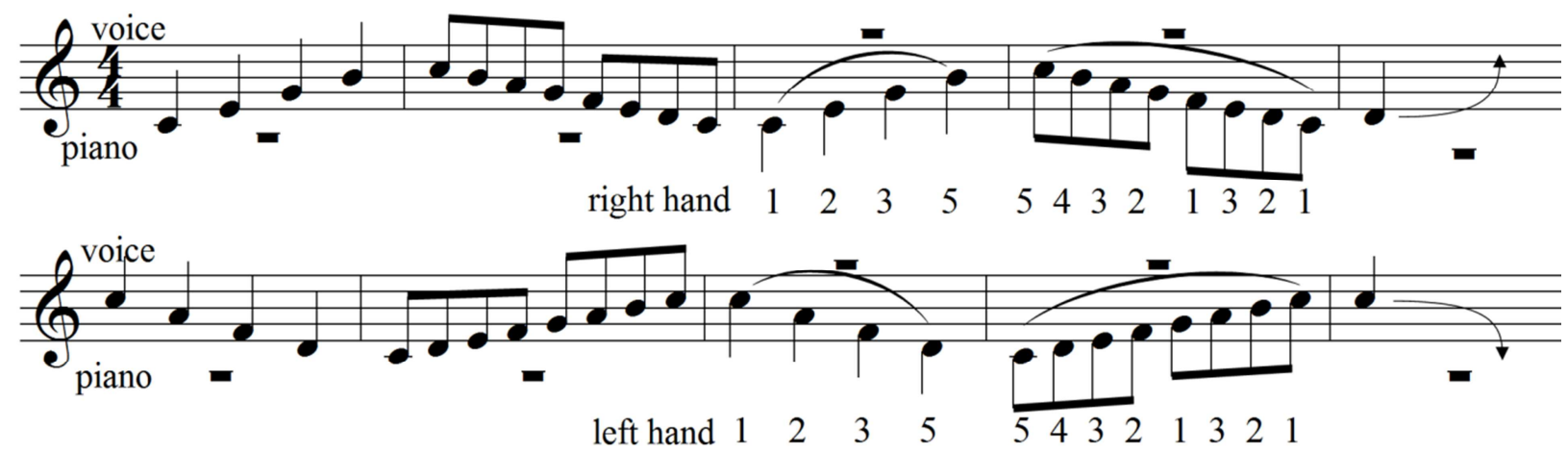

Figure 15. Seventh chord (heptachord).

Figure 15: - "Seventh chord" (heptachord) - In this example the learner gets to know with the term a four-note chord in its root position - seventh chord. The example is suitable for the introduction of the terms mode and scale.

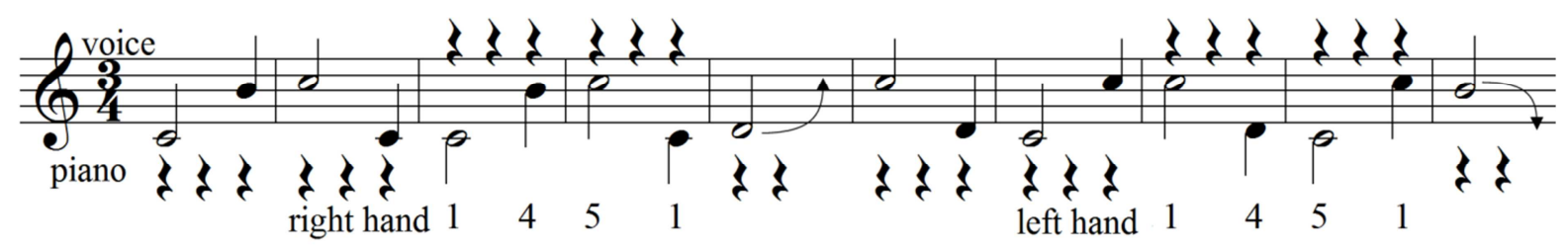

Figure 16. Seventh and octave. 
Figure 16: -"Seventh and octave"- Through the formed concepts in Example 14 for seventh chord and scale, here the learner's attention is directed to the intervals of seventh and octave.

The mentioned examples are proposed for studying and reinforcing each tonality in the next learning stages. In rhythmic aspect each of the main motifs can be changed according to the studied material.

\section{2. Construction Examples}

Construction examples in the group "dialogue" between voice and piano are aimed at developing a sight reading technique. Three types of construction examples are proposed:

- Using the bass clef.

- By changing the clef (solfegging in treble clef, playing on bass clef).

- Using two staves - on treble clef and bass clef

In the first type of construction examples the introduction of bass clef in the learning process as early as possible is dictated by the specificity of the considered activity solfegging with piano accompaniment. The wide range of the piano requires the constant presence of bass cleff in the music score.

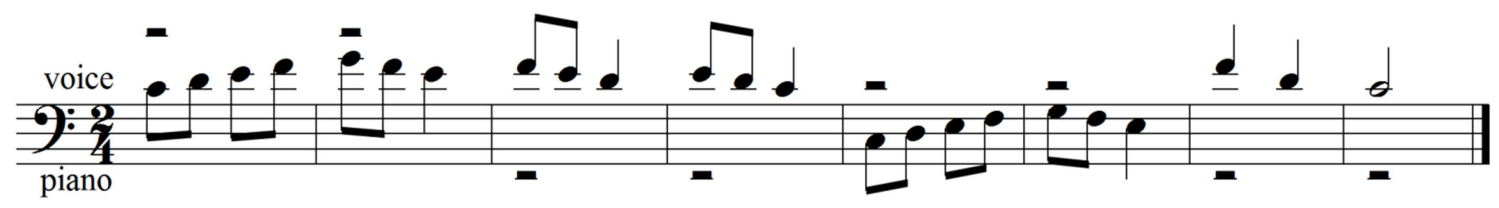

Figure 17. Dialogue between voice and piano using bass clef.

In the second type of exercise the two most commonly used music clefs are changing.

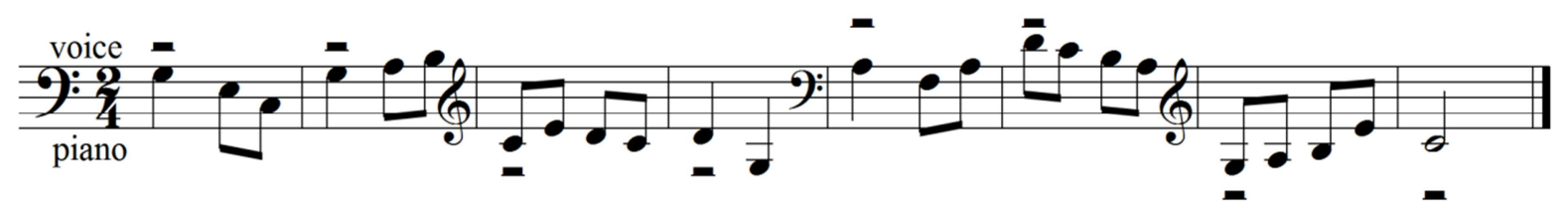

Figure 18. Dialogue between voice and piano by changing the clef.

The third type of exercises proposes examples noted on on a two-staff system. The aim is the gradually expansion of the visual range which provides the conditions for the conduct of the process chain - vision $\rightarrow$ inner hearing $\rightarrow$ motor response. This is a process chain which is based on the coparticipation of visual, motor and auditory concepts, supported by the piano keyboard.

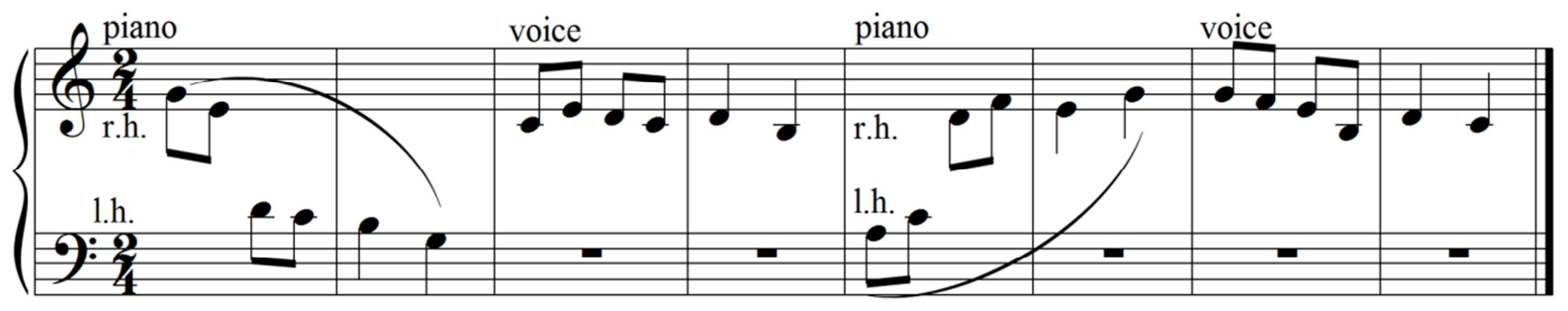

Figure 19. Dialogue between voice and piano using two staves - on treble clef and bass clef.

The exercises are designed in conjunction with the studied material. Prior to the performance, the scores are given to the learner so he can think of the sound, to pronounce the name of the notes and to touch the corresponding keys. The teacher assigns different artistic tasks after "examining" enough the studied "object":

- the teacher offers the students a melody for solfegging and the students compose a melody for playing (or vice versa), using particular elements;

- a student starts a melody, the teacher extend it and another student finishes it.

The works are written and played by each student individually. Such creative tasks form proper music mental skills - „from the inside outward", they are intended for the activation of the internal hearing.

The proposed examples - "dialogue" between piano and voice and the ways of working with them illustrate and explain the "first steps" to the actual implementation of the activity solfegging with piano self-accompaniment.

\section{Results}

In three school years a certain pedagogical activity was carried out through the activity solfegging with piano self- 
accompaniment (selected studying materials, used with specific and precise ways of working, "fitted" in other activities, with a definate "share" in the overall education), which showed high efficiency in the training. This is a good argument the activity to be "brought up" and presented as an object of study. The indicators which reported the effectiveness of the proposed method:

The learners:

- did pure intonation of melodies built up by neighboring second movement and by melodic leaps - thirds, fourths, etc.

- mastered the diatonics in C dur, a moll, F dur, d moll, G dur, e moll;

- performed note values rhythmic precisely (half notes, quarter notes, eight notes) organized in $2 / 4,3 / 4$, and $4 / 4$ time signature;

- mastered the piano keyboard;

- acquired the skills of sight reading and playing the piano music scores on treble and bass cleff;

- received permanent knowledge for intervals, triads, four-note chords and toanlities;

The results of the individual examination of each child, trained in the activity solfegging with piano selfaccompaniment were good - from very good $(4,50)$ to excellent (6) in six-point scale. This confirmed the conclusion of the high effectiveness of the proposed method. The achieved benefit and the overall favorable effect on the development of music ear of the students determined the purpose of this researc

\section{Conclusions}

All stated above allows concluding that:

- The intonation exercises- sequences create:

- visual concept for the tone position on its corresponding key;

- motive concept for the playing of the tone;

- aural concept and skills for the pure intonation of the tone;

- initial theoretical knowledge of the musical elements;

- playing the piano skills;

- additional conditioned reflex connections (visual motor and auditory motor conditioned reflexes) to produce the physiological basis of the music aural concepts.

- The constructive examples:

- develop sight-reading technique in the different clefs;

- gradually expand the visual range, providing the needed conditions for the process chain - vision $\rightarrow$ inner hearing $\rightarrow$ motor response;

- favor the formation and the development of internal hearing.

The introduction of the activity solfegging with piano selfaccompaniment in teaching solfege is directed to the practical learning of the various means of musical expression, which, in turn, to lead to the formation of habits and skills for independent, systematic and profound observations. The given examples and clarifications concerning the didactics in the implementation of the activity give a reason it to be indicated, on one hand, as a supporting activity of the learning process and on the other hand, as an activity illustrating the complex and mutually conditioned expression of all the elements of musical language.

I allege that this activity is reflexive, because during its practice a duality of consciousness and self-activity of the learner are revealed. The learner is both the object of reflection - "I - performer" and its subject - "I - controller". The successful conduct of the educational process is carried out with the active participation of the teacher. It is necessary the teacher himself/herself to have reflexive abilities on the basis of which to demonstrate models of pedagogic behavior, motivating the self-education.

The presented article indicates a starting point, which purposefully leads to mastering skills for solfegging with piano self-accompaniment. The given exercises solve intonation and rhythmic problems. The education is conducted on the basis of an individual aural and motor experience. The combination of voice timbre and the timbres of the different registers of the piano enriches the music perception. And last but not least, besides its main goal - the development of a good music ear, solfegging with piano selfaccompaniment contributes to the education of musical performance habits. Such basis helps future musicians to continue teach themselves and to be in touch with the new artistic tendencies, as well as to create independently.

\section{References}

[1] Berezhansky, P. N. Absolute Music Hearing, M., 2000 (Бережанский П. Н., „Абсолютный музыкальный слух”, M., 2000)

[2] Bochkarev, L. L. Psychology of Music Activities, Klassika XXI, 2008 (Бочкарёв Л. Л., „Психология музыкальной деятельности", Классика XXI, 2008)

[3] Desev, L. Pedagogical Psychology, edition Askoni, S., 1998 (Десев Л., „Педагогическа психология”, Аскони-издат, С., 1998)

[4] Jander O., „Solfeggio”, Harvard Dictionary of Music II Edition, Willi Apel, Belknap

[5] Karaseva, M. Solfeggio - Psychological technique for developing the music ear, edition Kompozitor, M., 2009 (Карасева М., „Сольфеджио - психотехника развития музыкального слуха”, изд. „Композитор”, М., 2009)

[6] Kirnarskaya, D. K. Musical Abilities, Talant XXI v., M., 2004 (Кирнарская Д. К., „Музыкальные способности”, Таланты XXI в., M., 2004)

[7] Kirnarskaya, D. K. Psychology of Music Activities, Talant XXI v., М., 2003 (Кирнарская Д. К., „Психология музыкальной деятельности”, Таланты XXI в., М., 2003)

[8] Popdimitrov, K. Method for Music Mental Technique on Voice and Instrumental Basis, NI, S., 1956 (Попдимитров К., „Метод за музикално мисловна техника върху гласова и инструментална основа", НИ, С., 1956) 
[9] Utkin, B. I. Education of the Professional Hearing of the Musician at School, Muzica, М., 1985 (Уткин Б. И., „Воспитание профессионального слуха музыканта в училище”, Музыка, М., 1985).
[10] Vygotsky, L. S. Art Psychology, Iskusstva, M., 1986 (Выготский Л. С., „Психология искусства”, Искусства, М., 1986) 